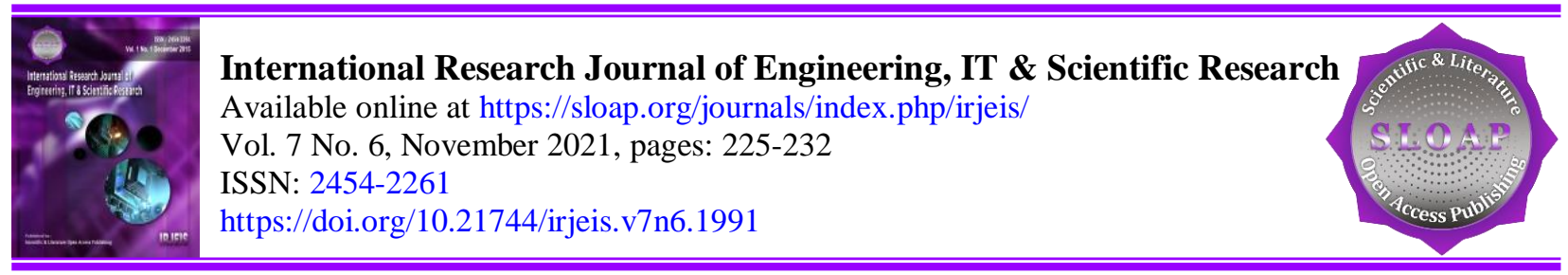

\title{
Formula "Ke-Kame-Tu" High Protein and Zinc as Basic Ingredients for Under Five Years Old Supplementary Feeding
} I Komang Agusjaya Mataram ${ }^{\text {a }}$
A. A. Gde Raka Kayanaya ${ }^{\text {b }}$

\section{Article history:}

Submitted: 18 September 2021

Revised: 09 October 2021

Accepted: 27 November 2021

\section{Keywords:}

formula;

PMT;

protein;

under five years old;

zinc;

\begin{abstract}
The aim of the research was to create a "ke-kame-tu" formula high in protein and zinc. Making the formula "ke-kame-tu" using a randomized block design, taste data obtained by organoleptic test followed by ANOVA analysis. Protein analysis using the micro-kjeldahl method, and zinc analysis using the spectrophotometric method. The "ke-kame-tu" formula consists of a mixture of moringa leaf flour, red bean flour and tuna fish flour with the following ratio (gram) that is F1 (15-70-15); F2 (15-60-25); F3 (15-50-35); F4 (15-4045); F5 (15-30-55); F6 (15-20-65). The nutritional content of the "ke-kametu" formula is as follows: a) Zinc content between $17.28 \%$ (F6) to $23.87 \%$ (F1), b) Protein content between $16.49 \%$ (F6) to $26.97 \%$ (F2), and c) Fat content is between $4.20 \%$ (F1) to $5.93 \%$ (F5). The ke-kame-tu formula contains complete essential amino acids, namely the amino acids histidine, threonine, arginine, methionine, valine, phenylalanine, iso leusie, leucine and lysine and as the limiting amino acid is methionine. Supplementary feeding (PMT) N1 protein content 10.138 g; N2 9.683 g; N3 9.097 g; N4 9.243 g; N5 $10,473 \mathrm{~g}$ and N6 10,197g. The best PMT based on the acceptability test by the panelists is the nugget product added with the F2 formula (15-60-25).
\end{abstract}

International research journal of engineering, IT \& scientific research (C) 2021.

This is an open access article under the CC BY-NC-ND license (https://creativecommons.org/licenses/by-nc-nd/4.0/).

Corresponding author:

I Komang Agusjaya Mataram,

Nutrition Department Health Polytechnic Denpasar, Bali, Indonesia.

Email address: komang_agusjaya@yahoo.com

${ }^{a}$ Nutrition Department Health Polytechnic Denpasar, Bali, Indonesia

${ }^{\mathrm{b}}$ Nutrition Department Health Polytechnic Denpasar, Bali, Indonesia 


\section{Introduction}

The high prevalence of stunting in Indonesia, including in Bali Province, is one of the nutritional problems that can result in the low quality of human resources. Nationally, in 2018 the incidence of stunting was still recorded at $30.8 \%$ and in the Province of Bali by $21.9 \%$. Some of the constraints that are still encountered include the ineffective and inefficient allocation and utilization of resources and funding sources as well as and limited capacity and quality of program implementation. The government has made great efforts to tackle the stunting problem, including specific and sensitive nutrition interventions. One of the specific nutritional interventions is zinc supplementation (Satriawan, 2018; Izwardy, 2019).

Activities that are routinely carried out in the integrated service post (posyandu) activities are the supplementary feeding (PMT) for under five years old. The distribution of PMT is through the center to the community health center and continued to the integrated service post. The cost required for the procurement of supplementary feeding is relatively large, but there is no specific study on the effectiveness of the supplementary feeding. Manufacturer toddler food packaged in aluminum foil with a net weight of 40 grams, containing 4 biscuits (@ 10 grams per piece in a round shape. The nutritional content per 100 grams is total energy $464.5 \mathrm{kcal}$, protein $8.45 \mathrm{~g}$, total fat $16.74 \mathrm{~g}$, sodium $283.18 \mathrm{mg}$, vitamin A $286.43 \mathrm{mcg}$, vitamin D $6.35 \mathrm{mcg}$, vitamin E $5,47 \mathrm{mcg}$, vitamin B1 $0.33 \mathrm{mg}$, vitamin B2 $0.35 \mathrm{mg}$, vitamin B3 $3.52 \mathrm{mg}$, vitamin B6 $0.25 \mathrm{mg}$, vitamin B12 $0.59 \mathrm{mcg}$, folate $85.47 \mathrm{mcg}$, iron $6.58 \mathrm{mg}$, iodine $91.26 \mathrm{mcg}$, zinc $3.5 \mathrm{mg}$, calcium $231.18 \mathrm{mg}$, Selenium $11.02 \mathrm{mg}$, phosphorus $183 \mathrm{mg}$, and fluorine $0.18 \mathrm{mg}$ (Rosha et al., 2016; Nur et al., 2020).

The "ke-kame-tu" formula is a formula with high protein and zinc content using local food, a mixture of moringa leaf flour, red bean flour and tuna fish flour. If this formula can be used as an alternative to PMT under five and can be produced in the regions by adopting local wisdom, it will be very profitable and more efficient in terms of availability, funding and acceptability (Dewi, 2011; Fadhilah, 2014). The food ingredients used for the formula ( Moringa, red beans and tuna) are well known to the public and marketed for consumption in traditional markets as well as in supermarkets or super markets. On average, ke-kame-tu per 100 grams of raw material contains $21.26 \mathrm{~g}$ of protein and $1.25 \mathrm{mg}$ of zinc. For example, the nutritional needs of toddler aged 1-3 years according to the Recommended Nutritional Adequacy Ratio (RDA), for protein as much as 20 grams and zinc as much as $3 \mathrm{mg}$. If kekame-tu is consumed as much as 100 grams, it can meet the nutritional needs for protein as much as $106.3 \%$ and zinc as much as 41.7\% (Mortimer et al., 2017; Garcia-Velasco et al., 2013).

The result of this research is a product in the form of flour that can be developed as the basic material for making PMT for toddlers. The nutritional content of the product, especially protein and zinc, will be able to help meet the nutritional needs of toddlers. The final expected impact is the optimal need for nutrients, especially protein and zinc, as well as optimal growth so that the incidence of nutritional problems, especially stunting, can be avoided. Zinc is one of the essential macro minerals for life. Zinc plays an essential role in many body functions including 1) Enzyme cofactor, 2) Metabolic aspect, 3) Maintenance of acid-base balance, 4) Protein digestion, 5) As part of the peptidase enzyme in pancreatic fluid, 6) An integral part of DNA polymerase. and RNA polymerase, 7) Part of the collagenase enzyme, 8) Plays a role in the synthesis and degradation of collagen, 9) Plays a role in skin formation, connective tissue metabolism and 10) Plays a role in the development of male reproductive function and sperm formation, 11) Plays a role in alcohol detoxification , 12) Plays a role in the metabolism of vitamin A, 13) Plays a role in immune function, 14) Plays a role in bone metabolism, oxygen transport, and the elimination of free radicals, and 15) Formation of membrane structure and function and the process of blood clotting. The need for zinc per day according to the Regulation of the Minister of Health of the Republic of Indonesia No. 28 of 2019 based on the age group 0-5 months as much as $1.1 \mathrm{mg}$; 6-11 months $3 \mathrm{mg}$; $1-3$ years $3 \mathrm{mg}$; 4-6 years as much as $5 \mathrm{mg}$ (Widyantara \& Sukaatmadja, 2019; Benedicta, 2021).

Proteins have specific functions that cannot be replaced by other nutrients, including 1) growth and maintenance (muscle, hair, skin, nails), 2) formation of essential bonds (thyroid, insulin and epinephrine; various enzymes; hemoglobin; photoreceptors in the eye); blood clotting; messengers between nerve cells), 3) Regulate water balance, 4) Maintain body neutrality, 5) Formation of antibodies, 6) Transport nutrients and 7) Source of energy. The need for protein per day according to the Regulation of the Minister of Health of the Republic of Indonesia No. 28 of 2019 based on the age group 0-5 months as much as $9 \mathrm{~g}$; 6-11 months $15 \mathrm{~g}$; 1-3 years as much as $20 \mathrm{~g}$; 4-6 years as much as $25 \mathrm{~g}$. Protein quality is determined by the type and proportion of amino acids it contains (Robinette, 1990; Wang, 2004). Complete protein or protein with high biological value or high quality is a protein that contains all types of essential amino acids in appropriate proportions for growth purposes. The essential amino acids for adults are 
histidine, threonine, tryptophan, methionine, valine, phenylalanine, iso-leucine, leucine, lysine. Babies also need the amino acid arginine.

\section{Materials and Methods}

The formulation of the kame-tu formula used a randomized block design (RAK) with 6 treatments and 3 replications. The comparison between moringa leaf flour, red bean flour and tuna fish flour is as follows F1 (15:70:15); F2 (15:60:25); F3 (15:50:35); F4 (15:40:45); F5 (15:30:55) and F6 (15:20:65). The making of supplementary feeding products used a randomized block design with 6 treatments and 3 replications. The ingredients for making nuggets are ground chicken, white bread, UHT milk, chicken eggs, bread flour, wheat flour, tapioca flour, carrots, pre leaves, and spices: garlic, salt, pepper powder, sugar, and broth. Chicken powder added 100 grams of ke-kame-tu formula according to treatment. The ke-kame-tu formula and supplementary feeding (PMT) products were analyzed for protein (microkjeldhal method) and zinc (spectrophotometric method). PMT taste test with organoleptic test, then carried out the analysis of variance (ANOVA). The ethical approval is submitted to the Ethics Committee of the Health Polytechnic Denpasar with the ethical approval Number: LB.02.03/EA/KEPK/0644/2021, dated August 5, 2021 (Krisnana \& Rachmawati, 2017; Almatsier, 2009).

\section{Results and Discussions}

\section{Result}

Nutrient content of formula ingredients

The yield of the ingredients are moringa (18.59\%), red beans (93.67\%) and tuna fish (21.85\%). The nutritional content of the formula ingredients consisting of zinc, protein, fat, ash and water were analyzed in the laboratory. The highest zinc content was found in red bean flour $(28.86 \%)$, the highest protein content was in tuna fish flour $(47.04 \%)$, and the highest fat content was found in moringa flour $(6.70 \%)$. (See Table 1$)$.

Table 1

Nutrient content of ingredients

\begin{tabular}{lccc}
\hline \multicolumn{1}{c}{ Nutrients } & Moringa leaf flour & Red bean flour & Tuna flour \\
\hline Zinc $(\%)$ & 20.04 & 28.86 & 15.62 \\
Protein $(\%)$ & 17.88 & 13.09 & 47.04 \\
Fat $(\%)$ & 6.70 & 2.24 & 1.64 \\
Ash $(\%)$ & 10.83 & 5.70 & 3.77 \\
Water $(\%)$ & 7.12 & 7.83 & 15.21 \\
\hline
\end{tabular}

The content of zinc, protein, fat, ash and water according to the treatment in the formula showed the following: a) Zinc content was between $17.28 \%$ (F6) to $23.87 \%$ (F1), b) Protein content was between $16.49 \%$ ( F6) to $26.97 \%$ (F2), formulas F1, F2 and F3 showed almost the same protein content, c) Fat content was between $4.20 \%$ (F1) to $5.93 \%$ (F5) (see Table 2).

Table 2

Average zinc, protein and fat content of ke-kame-tu formula

\begin{tabular}{lcccccc}
\hline \multicolumn{1}{c}{ Nutrients } & F1 & F2 & F3 & F4 & F5 & F6 \\
\hline Zinc $(\%)$ & 23.87 & 20.88 & 18.46 & 17.83 & 17.85 & 17.28 \\
Protein $(\%)$ & 26.22 & 26.97 & 26.35 & 19.53 & 17.70 & 16.49 \\
Fat $(\%)$ & 4.20 & 4.28 & 3.43 & 4.95 & 5.93 & 4.72 \\
Ash $(\%)$ & 5.25 & 5.23 & 5.05 & 5.60 & 5.30 & 5.05 \\
Water $(\%)$ & 7.06 & 7.9 & 8.07 & 7.63 & 9.11 & 8.18 \\
\hline
\end{tabular}

Mataram, I. K. A., \& Kayanaya, A. A. G. R. (2021). Formula "ke-kame-tu” high protein and zinc as basic ingredients for under five years old supplementary feeding. International Research Journal of Engineering, IT \& Scientific Research, 7(6), $225-232$. https://doi.org/10.21744/irjeis.v7n6.1991 
Note: The Ke-Kame-Tu formula is the ratio between moringa flour: red bean flour: tuna flour F1(15:70:15); F2(15:60:25); F3(15:50:35); F4(15:40:45); F5(15;30:55); F6(15:20:65)

The ke-kame-tu formula contains a complete list of essential amino acids and the limiting amino acid is methionine (see Table 3).

Table 3

Average amino acid content of ke-kame-tu formula

\begin{tabular}{lcccccc}
\hline \multicolumn{1}{l}{ Amino acid $(\% \mathrm{w} / \mathrm{w})$} & $\mathrm{F} 1$ & $\mathrm{~F} 2$ & $\mathrm{~F} 3$ & $\mathrm{~F} 4$ & $\mathrm{~F} 5$ & F6 \\
\hline Essential & & & & & & \\
1. Histidine & 0.95 & 1.52 & 2.29 & 3.21 & 2.76 & 3.97 \\
2. Threonine & 1.21 & 1.88 & 1.98 & 2.27 & 2.72 & 3.15 \\
3. Arginine & 2.19 & 2.58 & 3.10 & 3.23 & 3.72 & 4.33 \\
4. Methionine & 0.25 & 0.25 & 0.41 & 0.05 & 0.06 & 0.38 \\
5. Valine & 1.71 & 2.19 & 2.55 & 2.55 & 2.96 & 3.48 \\
6. Phenylalanine & 1.52 & 1.99 & 2.14 & 2.14 & 2.39 & 2.75 \\
7. Iso Leucine & 1.52 & 2.03 & 2.27 & 2.18 & 2.53 & 3.0 \\
8. Leucine & 2.41 & 3.15 & 3.71 & 3.71 & 4.36 & 5.13 \\
9. Lysine & 2.45 & 2.22 & 4.33 & 4.32 & 5.07 & 5.75 \\
Non Essential & & & & & & \\
1. Aspartic acid & 3.24 & 4.34 & 4.87 & 4.80 & 5.61 & 6.47 \\
2. Glutamic acid & 5.19 & 6.96 & 7.83 & 7.73 & 9.10 & 10.55 \\
3. Serine & 1.45 & 1.63 & 1.89 & 1.90 & 2.21 & 2.54 \\
4. Glysine & 1.08 & 3.12 & 2.40 & 2.46 & 2.92 & 3.26 \\
5. Alanine & 1.61 & 2.21 & 2.67 & 2.74 & 3.22 & 3.84 \\
6. Tyrosine & 0.95 & 1.27 & 1.52 & 1.52 & 1.85 & 2.14 \\
Amino acid total & 27.74 & 37.32 & 43.95 & 44.82 & 52.03 & 60.75 \\
\hline
\end{tabular}

Note: The Ke-Kame-Tu formula is the ratio between moringa flour: red bean flour: tuna flour

F1(15:70:15); F2(15:60:25); F3(15:50:35); F4(15:40:45); F5(15;30:55); F6(15:20:65)

Supplementary feeding nutrient contents

The protein content of nuggets is between $9.098 \%$ (N3) to $10.197 \%$ (N6). Nuggets fat content is between $2.857 \%$ to $4.161 \%$ (N6). Ash content is between $2.079 \%$ (N6) to $2.515 \%$ (N4). The water content is between $52.399 \%$ (N2) to $57.439 \%$ (N7) (see Table 4).

1

Table 4

Protein and fat content of supplementary feeding nugget per 100 grams

\begin{tabular}{lcccccc}
\hline \multicolumn{1}{c}{ Nutrients } & $\mathrm{N} 1$ & $\mathrm{~N} 2$ & $\mathrm{~N} 3$ & $\mathrm{~N} 4$ & $\mathrm{~N} 5$ & $\mathrm{~N} 6$ \\
\hline Protein $(\%)$ & 10.138 & 9.683 & 9.098 & 9.243 & 10.473 & 10.197 \\
Fat (\%) & 2.990 & 2.857 & 3.049 & 2.857 & 3.295 & 4.161 \\
Ash (\%) & 2.148 & 2.287 & 2.149 & 2.515 & 2.353 & 2.079 \\
Water (\%) & 54.764 & 52.399 & 55.930 & 54.119 & 57.439 & 57.174 \\
\hline
\end{tabular}

Note:

N1: nuggets added $100 \mathrm{~g}$ of formula ke-kame-tu F1; N2: nuggets added $100 \mathrm{~g}$ of formula ke-kame-tu F2;

N3: nuggets added $100 \mathrm{~g}$ of formula ke-kame-tu F3;; N4: nuggets added $100 \mathrm{~g}$ of formula ke-kame-tu F4;

N5: nuggets added $100 \mathrm{~g}$ of formula ke-kame-tu F5;; N6: nuggets added $100 \mathrm{~g}$ of formula ke-kame-tu F6; 


\section{Organoleptic test of supplementary feeding}

The organoleptic test of Nugget supplementary feeding products was carried out by panelists on aroma, color, taste, texture and overall. The panelists gave an assessment of the product by giving a score of 1-5 starting from the lowest score of (1) disliked to (5) very liked (Khotimah et al., 2000; Gandjar \& Rohman, 2012). The assessment of the aroma is between 3.7 (N6) to 4.1 (N1), which means that the nuggets to which the formula is added have the preferred aroma. The assessment of the color is between $3.6(\mathrm{~N} 1, \mathrm{~N} 6)$ to $3.8(\mathrm{~N} 4)$, meaning that the color of the product is considered favored. The assessment of the taste is between $3.3(\mathrm{~N} 5, \mathrm{~N} 6)$ to $4.0(\mathrm{~N} 2)$, meaning that the taste of the product is considered sufficient $(\mathrm{N} 5, \mathrm{~N} 6)$ to be liked. The assessment of the texture is between 3.4 (N1) to 3.8 (N3), meaning that the texture of the product is preferred except for $\mathrm{N} 1$ which is considered sufficient. The overall rating is between $3.5(\mathrm{~N} 5, \mathrm{~N} 6)$ to $4.0(\mathrm{~N} 3)$, meaning that the overall product $(\mathrm{N} 3)$ is preferred (see Table 5).

Table 5

Results of PMT nugget organoleptic tests according to treatment of aroma, color, taste, texture and overall

\begin{tabular}{cccccc}
\hline Treatment & Aroma & Color & Taste & Texture & Overall \\
\hline N1 & $4.10 \mathrm{a}$ & $3.6 \mathrm{a}$ & $3.63 \mathrm{ab}$ & $3.47 \mathrm{~b}$ & $3.77 \mathrm{abc}$ \\
N2 & $4.07 \mathrm{ab}$ & $3.7 \mathrm{a}$ & $4.00 \mathrm{a}$ & $3.70 \mathrm{ab}$ & $3.97 \mathrm{a}$ \\
N3 & $3.93 \mathrm{ab}$ & $3.7 \mathrm{a}$ & $3.97 \mathrm{a}$ & $3.87 \mathrm{a}$ & $4.07 \mathrm{a}$ \\
N4 & $3.77 \mathrm{ab}$ & $3.8 \mathrm{a}$ & $3.67 \mathrm{ab}$ & $3.77 \mathrm{ab}$ & $3.87 \mathrm{ab}$ \\
N5 & $3.73 \mathrm{~b}$ & $3.7 \mathrm{a}$ & $3.33 \mathrm{~b}$ & $3.57 \mathrm{ab}$ & $3.50 \mathrm{c}$ \\
N6 & $3.77 \mathrm{ab}$ & $3.6 \mathrm{a}$ & $3.37 \mathrm{~b}$ & $3.77 \mathrm{ab}$ & $3.57 \mathrm{bc}$ \\
\hline
\end{tabular}

Note: letters behind the same number show no difference

\section{Discussions}

The highest zinc content was found in red bean flour $(28.86 \%)$, the highest protein content was in tuna fish meal (47.04\%), and the highest fat content was found in Moringa flour (6.70\%) (Table 1). The ingredients of this formula have their respective advantages in terms of zinc, protein and fat content. The formulation of the formula using these ingredients will complement each other so that the desired formula is obtained, namely a high protein and high zinc formula. The ke-kame-tu formula is a mixture of moringa flour, red bean flour and tuna fish flour, with six formula combinations. Table 3 shows the zinc content between $17.28 \%$ (F6) to $23.87 \%$ (F1). The protein content is between $16.49 \%$ (F6) to $26.97 \%$ (F2), the formulas F1, F2 and F3 show almost the same protein content. The fat content is between $4.20 \%$ (F1) to $5.93 \%$ (F5). The amino acid content of the ke-kame-tu formula as the limiting amino acid is methionine (see Table 3) (Arikunto, 2010; Daniel \& Cross, 2018; Aminah et al., 2015).

It is hoped that this formula can be used as a substitute for fulfilling nutritional needs, especially protein and zinc. For toddlers aged 11 months, they need to consume 15 grams of protein and $3 \mathrm{mg}$ of zinc. By consuming 10 grams of F6 formula which has the lowest protein and zinc content among the 6 formulas, it will help fulfill $11 \%$ protein consumption and 57\% zinc consumption. If the F2 formula is consumed as much as 10 grams, it will be able to meet higher protein needs, namely $18 \%$ and zinc as much as $70 \%$. The importance of protein and zinc consumption because these two nutrients have an important role in the period of growth and development of toddlers. The role of protein is for the growth and maintenance of cells in the body, while the fulfillment of zinc needs will greatly assist the normal development of the fetus (Fukushima et al., 1998; Willatts et al., 1998).

The ke-kame-tu formula contains complete essential amino acids and limiting amino acids, namely methionine ( $0.05 \mathrm{~F} 4$ to $0.38 \mathrm{~F} 6$ ). If the ke-kame-tu formula is consumed according to the needs of toddlers, it will have an impact on optimal growth. To prevent the birth of babies with low body weight (LBW), this formula can also be used as PMT for pregnant women. The research of Mataram et al. (2017), made high protein PMT based on the kahiguru formula (green beans, gude beans, lemuru fish) containing complete essential amino acids and as a limiting amino acid is lysine. The supplementary feeding products made were chicken nuggets to which the ke-kame-tu formula was added according to the treatment, namely N1: nuggets to which $100 \mathrm{~g}$ were added to the ke-kame-tu formula F1; N2: nuggets added $100 \mathrm{~g}$ of formula to-kame-tu F2; N3: nuggets added $100 \mathrm{~g}$ of formula to-kame-tu F3; N4: nuggets added $100 \mathrm{~g}$ of formula to-kame-tu F4; N5: nugget added $100 \mathrm{~g}$ of formula to-kame-tu F5 and N6: nugget added 100 $\mathrm{g}$ of formula to-kame-tu F6 (Rahmati et al., 2019; Kooijman, 2006).

Mataram, I. K. A., \& Kayanaya, A. A. G. R. (2021). Formula "ke-kame-tu" high protein and zinc as basic ingredients for under five years old supplementary feeding. International Research Journal of Engineering, IT \& Scientific Research, 7(6), 225-232. https://doi.org/10.21744/irjeis.v7n6.1991 
The protein content of nuggets is between $9.098 \%$ (N3) to $10.197 \%$ (N6). Nuggets fat content is between $2.857 \%$ to $4.161 \%$ (N6). Ash content is between $2.079 \%$ (N6) to $2.515 \%$ (N4). The water content is between $52.399 \%$ (N2) to $57.439 \%$ (N7) (Table 4). To determine the level of preference for nugget products, organoleptic tests were carried out using moderately trained panelists. Assessments were made on aroma, color, taste, texture and overall acceptance. The results showed that the preferred aroma was nugget N1, or N2, or N3, or N4 and N6 and for color all formulas were preferred. Preferred flavors are PMT N2, or N3, or N4 or N1. The texture of almost all PMT is preferred (N2, N3, N4, N5, N6). The overall admission is PMT N3, or N2, or N4 or N1 (Table 5). Based on table 3 and table 5, it can be concluded that the nugget product that can be applied in the field is the nugget product with the added formula to-kame-tu F2. The N2 nugget product weighing 25 grams has a protein content of 9.683 grams and zinc at $0.37 \mathrm{mg}$. (Table 3 and Nutricheck). If this nugget is consumed by a toddler aged 11 months as much as 100 grams, it will be able to meet the adequacy of protein as much as $64.5 \%$ and zinc as much as $49 \%$ (Lawrence \& Colman, 1993; Becker, 2007).

\section{Conclusion}

1) Moringa leaf flour yield (18.59\%), red beans (93.67\%) and tuna fish (21.85\%); 2) The ke-kame-tu formula is high in protein and zinc consisting of a mixture of Moringa leaf flour, red bean flour and tuna fish meal, namely F1 (1570-15); F2 (15-60-25); F3 (15-50-35); F4 (15-40-45); F5 (15-30-55); F6 (15-20-65); 3) The nutritional content of the "ke-kame-tu" formula is as follows: a) Zinc content ranges from $17.28 \%$ (F6) to $23.87 \%$ (F1), b) Protein content ranges from $16.49 \%$ ( F6) to $26.97 \%$ (F2), c) Fat content ranges from $4.20 \%$ (F1) to $5.93 \%$ (F5). Its essential amino acid content is complete, namely containing the amino acids histidine, threonine, arginine, methionine, valine, phenylalanine, iso leusie, leusine and lysine and as a limiting amino acid is methionine, 4) Protein content of supplementary feeding (PMT) N1 $10.138 \mathrm{~g}$; N2 $9.683 \mathrm{~g}$; N3 $9.097 \mathrm{~g}$; N4 9.243 g; N5 10,473g and N6 10,197g. The best PMT based on the acceptability test by the panelists is the nugget product added with the F2 formula (15-60-25). The PMT N2 formula is expected to be applied to the provision of PMT during integrated service post (posyandu) activities. If PMT N2 is consumed as much as 100 grams, it will be able to meet the protein needs of toddlers aged 611 months as much as $64.5 \%$. With a complete content of essential amino acids, it is hoped that it will ensure optimal growth processes in toddlers, so that stunting events can be eliminated.

\section{Suggestion}

Supplementary feeding (PMT) in the form of nuggets is very likely to be applied in posyandu to help meet protein needs with good quality.

\section{Conflict of interest statement}

The authors declared that they have no competing interest.

\section{Statement of authorship}

The authors have a responsibility for the conception and design of the study. The authors have approved the final article.

\section{Acknowledgments}

Further thanks to the director and head of the department of nutrition Denpasar for the support that has been given. Also to the Head of the Laboratory of Basic Sciences, Faculty of Agriculture, Warmadewa University, Denpasar and the Laboratory for Testing, Calibration and Certification Services, Bogor Agricultural University, thank you for your willingness to carry out proximate, zinc and amino acid analysis. 


\section{References}

Almatsier, S. (2009). Basic principles of nutrition science. Jakarta: Gramedia Pustaka Utama.

Aminah, S., Tezar, R., \& Muflihani, Y. (2015). Nutrient content and functional properties of Moringa oleifera. Urban Agriculture Bulletin, 5(2), 35-44.

Arikunto, S. (2010). Research procedure a practical approach. Jakarta: Rineka Cipta, 152.

Becker, E. W. (2007). Micro-algae as a source of protein. Biotechnology advances, 25(2), $207-210$. https://doi.org/10.1016/j.biotechadv.2006.11.002

Benedicta, O. (2021). Relationship between competitive intelligence and competitive advantage in manufacturing industry. International Research Journal of Management, IT and Social Sciences, 8(5), 342-351. https://doi.org/10.21744/irjmis.v8n5.1908

Daniel, W. W., \& Cross, C. L. (2018). Biostatistics: a foundation for analysis in the health sciences. Wiley.

Dewi, T. K. S. (2011). Kearifan Lokal Makanan Tradisional: Rekonstruksi Naskah Jawa dan Fungsinya dalam Masyarakat. Manuskripta, 1(1), 161-182.

Fadhilah, A. (2014). Budaya pangan anak singkong dalam himpitan modernisasi pangan: eksistensi tradisi kuliner rasi (beras singkong) komunitas kampung adat Cireundeu Leuwi Gajah Cimahi Selatan Jawa Barat. Buletin AlTuras, 20(1), 13-30.

Fukushima, Y., Kawata, Y., Hara, H., Terada, A., \& Mitsuoka, T. (1998). Effect of a probiotic formula on intestinal immunoglobulin A production in healthy children. International journal of food microbiology, 42(1-2), 39-44. https://doi.org/10.1016/S0168-1605(98)00056-7

Gandjar, I. G., \& Rohman, A. (2012). Analisis obat secara spektrofotometri dan kromatografi. Yogyakarta: Pustaka Pelajar, 316, 368-381.

Garcia-Velasco, J. A., Domingo, J., Cobo, A., Martínez, M., Carmona, L., \& Pellicer, A. (2013). Five years' experience using oocyte vitrification to preserve fertility for medical and nonmedical indications. Fertility and sterility, 99(7), 1994-1999. https://doi.org/10.1016/j.fertnstert.2013.02.004

Izwardy, D. (2019). Kebijakan dan strategi penanggulangan stunting di Indonesia. Gerakan masyarakat hidup sehat, $1-64$.

Khotimah, I. K., Sudarmadji, S., \& Rahardjo, S. (2000). Physical properties and sensory comparison of Ca-Alginate and NaCl-phosphate restructured meat of eel (Monopterus albus Z.). In Prosiding Seminar Nasional Industri Pangan, Surabaya (Indonesia), 10-11 Oct 2000. Perhimpunan Ahli Teknologi Pangan Indonesia.

Kooijman, P. (2006). Multi-PMT optical module. Nuclear Instruments and Methods in Physics Research Section A: Accelerators, Spectrometers, Detectors and Associated Equipment, 567(2), 508-510. https://doi.org/10.1016/j.nima.2006.05.272

Krisnana, I., \& Rachmawati, P. D. (2017). Improving Knowledge of Posyandu Cadre About PMT to Prevent Malnutrition on Children. Pediomaternal Nursing Journal, 4(1), 1-5.

Lawrence, M. C., \& Colman, P. M. (1993). Shape complementarity at protein/protein interfaces. https://doi.org/10.1006/jmbi.1993.1648

Mataram, I., Laraeni, Y., \& Agustini, N. P. (2017). Formula kahiguru high protein for making of food supplement as elimination stunting. International Journal of Life Sciences Vol. 1 No. 3, December 2017, pages: 14 27, 1(3), 14-27.

Mortimer, K., Ndamala, C. B., Naunje, A. W., Malava, J., Katundu, C., Weston, W., ... \& Gordon, S. B. (2017). A cleaner burning biomass-fuelled cookstove intervention to prevent pneumonia in children under 5 years old in rural Malawi (the Cooking and Pneumonia Study): a cluster randomised controlled trial. The Lancet, 389(10065), 167-175. https://doi.org/10.1016/S0140-6736(16)32507-7

Nur, L., Nurani, L. A., Suryana, D., \& Ahmad, A. (2020). Rasch model application on character development instrument for elementary school students. International Journal of Learning, Teaching and Educational Research, 19(3), 437-459.

Rahmati, O., Kornejady, A., Samadi, M., Deo, R. C., Conoscenti, C., Lombardo, L., ... \& Bui, D. T. (2019). PMT: New analytical framework for automated evaluation of geo-environmental modelling approaches. Science of the total environment, 664, 296-311. https://doi.org/10.1016/j.scitotenv.2019.02.017

Robinette, C. L. (1990). Zinc. Veterinary Clinics of North America: Small Animal Practice, 20(2), 539-544. https://doi.org/10.1016/S0195-5616(90)50044-3

Mataram, I. K. A., \& Kayanaya, A. A. G. R. (2021). Formula "ke-kame-tu” high protein and zinc as basic ingredients for under five years old supplementary feeding. International Research Journal of Engineering, IT \& Scientific Research, 7(6), 225-232.

https://doi.org/10.21744/irjeis.v7n6.1991 
Rosha, B. C., Sari, K., Yunita, I. S., Amaliah, N., \& Utami, N. H. (2016). Roles Of Sensitive And Specific Nutritional Interventions In The Improvement Of Nutritional Problems In Bogor. Buletin Penelitian Kesehatan, 44(2), 127-138.

Satriawan, E. (2018). National Strategy for the Acceleration of Stunting Prevention 2018-2024. Jakarta: National Team for the Acceleration of Poverty Reduction (TNP2K).

Wang, Z. L. (2004). Nanostructures of zinc oxide. Materials today, 7(6), 26-33. https://doi.org/10.1016/S13697021(04)00286-X

Widyantara, I. N. P., \& Sukaatmadja, I. P. G. (2019). Formulation of chicken egg marketing strategy. International Research Journal of Management, IT and Social Sciences, 6(5), 285-302. https://doi.org/10.21744/irjmis.v6n5.771

Willatts, P., Forsyth, J. S., DiModugno, M. K., Varma, S., \& Colvin, M. (1998). Effect of long-chain polyunsaturated fatty acids in infant formula on problem solving at 10 months of age. The Lancet, 352(9129), 688-691. https://doi.org/10.1016/S0140-6736(97)11374-5 